\title{
ASSESSMENT OF LOGISTIC CUSTOMER SERVICE IN THE CEP SECTOR ON THE EXAMPLE OF CRACOW
}

\author{
AUGUSTYN LORENC \\ Cracow University of Technology, POLAND \\ e-mail: alorenc@pk.edu.pl
}

RECEIVED
ACCEPTED
JEL
CLASSIFICATION

KEYWORDS

ABSTRACT
20 June 2017

15 December 2017

R41, L21, 91, L87

Logistics customer service, courier services, CEP market, last mile

The services sector of Courier Expressways and parcel (CEP) is one of the fastest-growing service sectors. This is due to a specific evaluation of quality by customers in the final stage of the supply chain - what has been called the last mile problem.

Logistics customer service is a key tool for building the company's competitiveness in the market. This article evaluates the effectiveness of X-Press Couriers customer service focused primarily on timely delivery of services and the number of complaints filed. Acquisition of information on this subject was allowed by access to the complaint database and the Trucker system. The characteristics of the courier business in Poland and the assessment of cooperation with Polish companies of TSL was done. On the basis of the research conducted by the SGH Center for Economic Counseling and Expertise, the impact of KEP on Polish companies was illustrated. Data provided by the X-Press Couriers division of Cracow allowed us to focus on one of the most important logistic measures of customer service, ie the timeliness of service. The presented data is based on the knowledge gained while working in this company and on the collected statistics.

\section{Introduction}

The definition of the courier service according to the Act (Dz.U. 2003, nr 330, poz. 1188) states that it is not universal in nature and relies on expedited shipping and delivery of consignments at guaranteed time (Dz.U., 2003). The CEP services (Courier, Express and Parcel) is the most dynamically developing sector in the TFL market (Transport-Forwarding-Logistics). The reason for this fact is that companies invest in modern technology and care 
about the quality of customer service. Small courier companies tend to merge to strengthen their position on the market. However, in spite of their reputation they have to strive for continuous improvement in efficiency, in order to ensure a high level of service.

Creating a proper courier business in Poland can accept the year 1989, which was also a period of socioeconomic changes in our country. The emergence of competing companies, the introduction of free market rules, and the release of individual economic initiatives at the time were significant facilitation (Jacyna-Gołda, Pyza, Szczepański, 2015). The following courier companies were established: Opek (1994), Stolica (1993), Kurierserwis (1992) and Masterlink Express (1991). The interest was so great that the advantage of the good conditions created their subsidiaries in Polish, thus mastering a significant part of the market (Pliszka, 2008).

In addition to foreign leaders, Polish companies based on small capital have also developed. Their path to being in the industry was much more difficult, but they built the infrastructure and brand recognition with endurance. This allowed them to grow enough to become the best players in the industry (Kawa, 2011; Lorenc, Szkoda, 2015).

By the end of 2014, officially completed the acquisition of all shares of Siódemka by DPD Polska. Both companies are at the forefront of courier services, so DPD will take over $20 \%$ of the market through this transaction. Such a large scale allowed them to increase their capabilities and combine the strengths of both companies. The use of modern IT solutions and experience of Siódemka, networks and infrastructure DPD will gain a competitive advantage and increase the quality of services.

In smaller organizations, working from a dozen to several dozen employees. These companies mainly offer services in local and national services, and they also have low transport potential. Some of them, thanks to cooperation with larger companies, also carry out international shipments. These companies are much more than the previous ones, as can be mentioned here: X-Press Couriers, Agap, Victorio, Transervis, and Koliber Express. The last group is small entities that provide courier services exclusively at local level. Their means of transport mostly include bicycles, motorcycles and scooters. This idea thrives mainly in large Polish cities, which are usually impassable during peak hours. The local service is designed to transport a package (usually documents) within a single city in the shortest possible time. This last stage is particularly important - it attracted the attention of companies such as Amazon and DP at Warehouse Management Symposium in Warsaw in 2016. Price of delivery is dependent on the required time of delivery and distance between the sender and the recipient. Companies implementing such services are: Maraton (Poznań), Bike Post (Warszawa), Kurierzy Rowerowi (Katowice), Błyskawica (Gdańsk).

The advantage of small, local courier companies is a very good knowledge of the market and an individual approach to the customer. They have a much greater ability to adapt to customer needs and market needs. This allows the customer to feel comfortable and does not always carry a higher price compared to the leader in the field (Lendzion, 2013).

\section{Evaluation of cooperation with companies in the TSL industry}

Adequate treatment of value creation networks, including those focused on market needs, has a significant impact on customer value creation and builds a competitive advantage for the company. Managing a value-creation system while respecting the principles of logistic thinking and action is the main task of operational management. The formation of this logistic system is, on the other hand, a crucial issue of integrated strategic at a higher level of management. 
The popularity of individual carriers among individual and business customers is shown in Figure 1 (Dyczkowska, 2005).

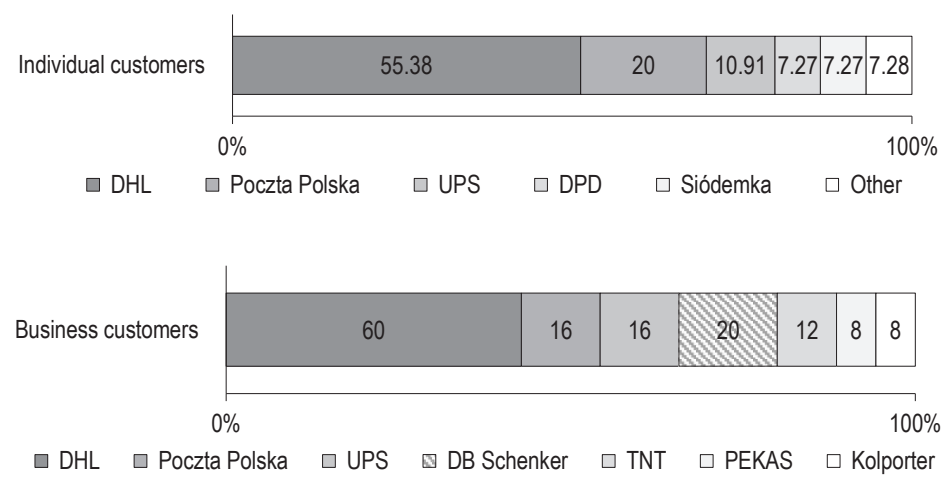

Figure 1. The popularity of courier companies among individual and business customers

Source: Dyczkowska (2005).

The diagrams shown in Figure 1 show that $\mathrm{DHL}$ is the most popular carrier for both individual and business customers. Individual customers benefit from the services of a much narrower group of carriers. This is due to the fact that almost $80 \%$ of them send only parcels and other consignments are small one. The second one is Poczta Polska, $20 \%$ of respondents use it, and the other companies (UPS, DPD and others) are much less popular. Once again, the business looks the opposite of business customers. In addition to the leader, i.e. DHL, institutional clients benefit from the services of DB Schenker (20\%), UPS (16\%), Poczta Polska (16\%) and TNT (12\%). $8 \%$ of respondents in this group entrusts the conveyance of the company Pekas and Kolporter. In companies $88 \%$ of cargo is small, $12 \%$ is parcel and $4 \%$ is partial or documents (Rutkowski, 2011), (Cichosz, Nowicka, Pluta-Zaremba, 2011).

Another aspect taken into account are the criteria for selecting the carrier, which are presented in Table 1.

Table 1. Criteria for choosing a transport company by individual and institutional clients (\%)

\begin{tabular}{lcc}
\hline \multicolumn{1}{c}{ TSL selection criteria } & Individual customers & Business customers \\
\hline Costs & 76 & 84 \\
Reliability & 49 & 56 \\
Convenience & 40 & 44 \\
Flexibility of action & 20 & 32 \\
Good communication & 38 & 44 \\
Company size & 5 & 4 \\
Other & 5 & 0 \\
\hline
\end{tabular}

Source: Dyczkowska (2005).

The most important feature, according to which the carrier chooses more than $76 \%$ of individual customers and $84 \%$ of institutional clients is the cost of the service. The second important feature is reliability and timeliness, 
half of respondents from both groups indicate that they are important in the choice of transport. Another important thing for customers is convenience, defined as the realization by one transport company of the transport of different types of goods (parcels, general cargo, etc.). Another criterion is the flexibility of operation and execution of custom orders, $20 \%$ of individual customers and $32 \%$ of companies pay attention to this. The respondents are also not indifferent to good contact and cooperation with the transport company. More than $38 \%$ of individuals and $44 \%$ of organizations think that customer service is crucial when choosing the right carrier.

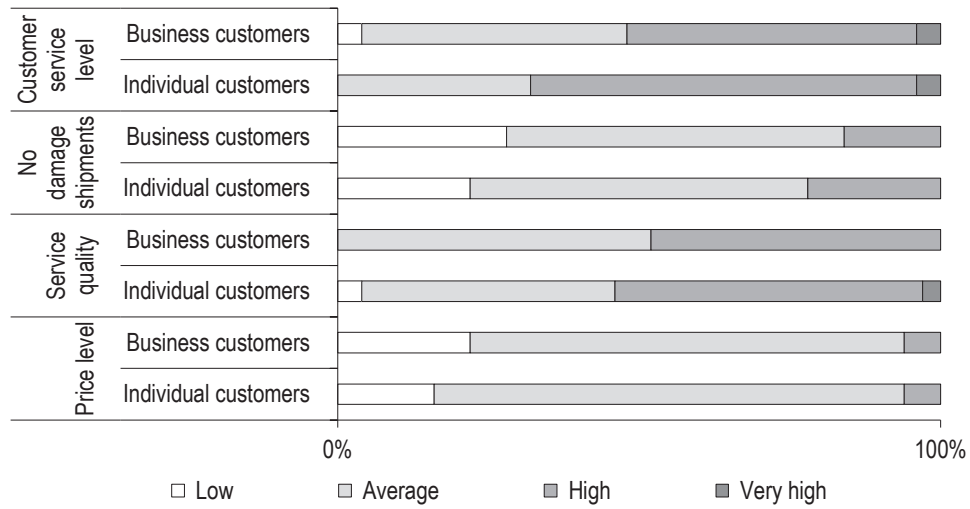

Figure 2. The rating criteria for individual and business customers

Source: Dyczkowska (2005).

Market research shows that when selecting a transport operator, the customer points to three main features: cost, timeliness and quality. The scale of the phenomenon is so much larger among companies that they better assess the timeliness of shipments and their safety (carriage of parcels in undamaged condition). For both groups, customer service is equally important. By analyzing more in detail, institutional clients rate it at a much higher level than individual clients (Figure 2). It is also related to the fact that the first group cooperates with carriers very often. In addition, organizations pay close attention to the convenience and flexibility of logistic operators. Treating the customer as an individual and adapt to their needs can help the client to use the services he offers. Increased access to information, the ability to compare offers, increased customer demand for the range of services, and a large number of carriers on the market mean that logistics operators must constantly focus on building a competitive advantage.

\section{Efficiency of logistic customer service on the example of a Iocal company in Cracow}

X-press Couriers is the main local express delivery company in Cracow. X-press Couriers was founded in 1996. Initially it was called X-press Bikers. The name refers to the service that launched its existence on the market, that is, the execution of express orders of local bicycle transport in Warsaw. The company was one of the first bicycle couriers used performance in one of the most congested cities in Europe. 
The first years of the activity were aimed at the expansion of centers in other Polish cities. In 2008, it had branches in cities like Warsaw, Cracow, Wroclaw, Szczecin, Poznań and Łódź. The company built its position on the local services market, but with the consequence the company expanded its operations to execute orders throughout Poland and in 230 countries around the world ("X-press," 2017). X-press Couriers employs car and bicycle couriers, offers single and freight services, and works with industry leaders CEP.

In addition, the company is pursuing a strategy to develop a network of multi-functional customer service points. X-Store boutiques, usually located in large business centers, provide postal and courier services (including the proper preparation of shipments for transport).

Logistics customer service is a key element that gives the company a competitive advantage. Ability to adapt to the needs and expectations of customers, translates into trust and builds good relationships with the buyer. The Local Services Segment allows you to adapt to the following requirements:

- readiness to receive,

- service time,

- shipment size,

- price,

- payment method,

- additional services (insurance, acknowledgment of receipt).

In Cracow branch local services are implemented in four basic services:

- Pośpiech (L PS) - service time from the time of placing an order is 5 hours,

- X-press (LXP) - service time since the order is 2 hours,

- Premium (L PREM) - direct course, the service time from the time the order is placed is an hour,

- Wojewódzki X-press (W XP) - service time from the time of placing an order is 3 hours.

In Warsaw local services are implemented on completely different principles, however, due to affiliation to the network courses made for customers in other cities in Warsaw are performed on the service New X-press (L NXP) - delivery time from the order is 3 hours.

Cracow is divided into three zones, urban and provincial zone (within which the service is performed Wojewódzki X-press). The price of the service varies depending on the delivery address, size, and delivery time. The whole decision-making process begins at the time the order is placed by the customer and often it is the customer's decision that the service will be delivered on time. Dispatcher to assign the driver to the appropriate order must take into account:

- the place of origin and of delivery,

- weight of shipment,

- dimensions of shipment,

- readiness to receive,

- order execution time (customer service declared by the customer),

- traffic,

- the amount of work a courier must carry out,

- route optimization,

- atmospheric conditions. 
The key factor influencing the efficiency of logistic customer service is timely. Therefore, the accompanying statistics derived from the Krakow branch of X-press Couriers, will examine their effectiveness in the implementation of courses in the city and surrounding area. The obtained data allow also noted that orders for local service Lokalny Pośpiech are usually in the morning (between 8:00-11:00). This shows that customers depends on delivery during normal business hours (until the end of the working day). Local X-press services are most popular in the afternoon when delivery is required on the same day, and time is limited. Local Premium, as the fastest service that works best on urgent matters without any delay.

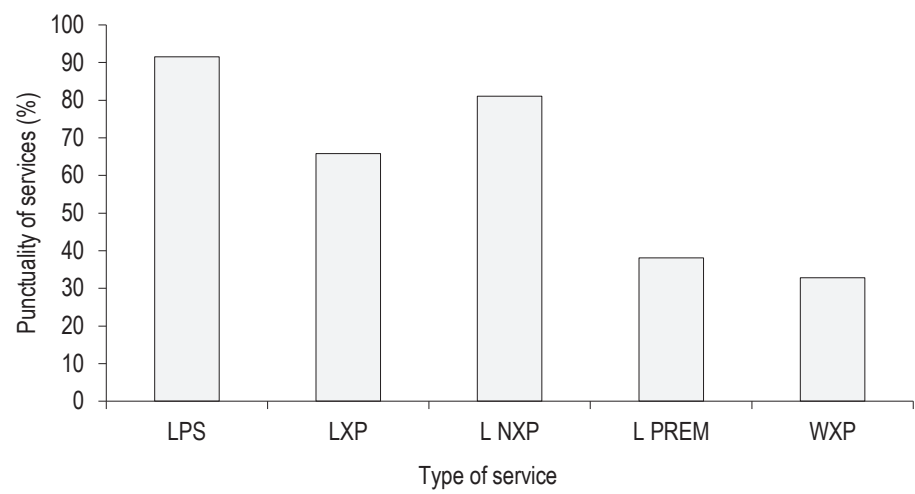

Figure 3. Punctuality by type of services

Source: own elaboration.

Figure 3 shows the timeliness of individual sites in 2014. It is easy to see that the branch complies with the timeliness of Cracow on a very different level. The service that has proven to be the most popular also enjoys the highest level of punctuality. More than $91 \%$ of courses are performed according to the time of service. At the same high level courses are offered at the New Xpress press center. Local X-press, a service performed in two hours, is performed on time in $65.8 \%$. However, only one third course in Local Premium or Provincial X-press is delivered on time.

Figure 4 shows the number of services delivered on time. The bar chart shows the exact number of them in each month. It can be seen that the first half of the year was filled with the highest number of delays (in the first four months the average remained around 50 courses, i.e. about $20 \%$ of all courses). The second half of the year was much more effective for the division, excluding December, which in the CEP industry is one of the heaviest periods of the year. During the holiday season, the Warsaw branch completely suspends local services and other branches try to realize them as far as possible.

The share of delayed deliveries for all realized rates for a given month does not exceed $20 \%$. Here, you can notice the difference between the first and the second half of the year. Holiday months, July and August, are socalled "downtime periods" for the courier service. This reflects the number of courses completed in this period. It does not drastically decrease, but with this scale already a dozen orders less impact on the formation of statistics. 


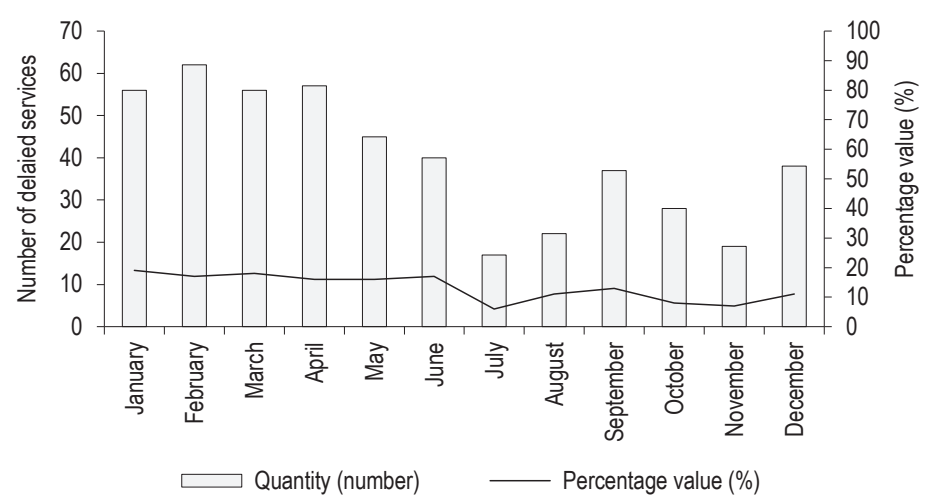

Figure 4. Delayed courses in individual months, numerical values and percentages

Source: own elaboration.

Another element of the assessment of the effectiveness of customer service logistics are complaints. The main cause of complaints are service delays and thus customer dissatisfaction. According to statistics provided by the Cracow branch, only 5 complaints concerning local courses were recorded.

Further data shows how timely delivery of guaranteed services. X-press and Super X-press, $89.7 \%$ of domestic shipments sent on X-press are delivered on time, while Super Xpress has $99.8 \%$ punctuality. Super X-press service is the most expensive domestic service offered by the company and its delivery time is firmly kept.

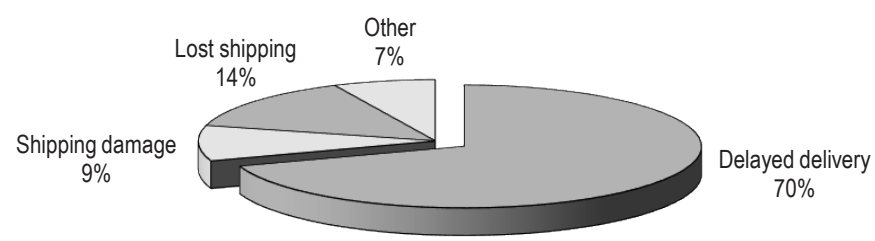

Figure 5 . Reasons for submitting complaints by clients

Source: own elaboration.

The main reason for the dissatisfaction of contractors was delays in delivery. Almost $70 \%$ of the complaints concerned services not delivered on time. Two other reasons are: loss or damage to the shipment by the carrier. The first one complained to $14 \%$ of customers and to damage $9.3 \% .7 \%$ of complaints concern the mistakes of own office workers or couriers. Here you can include, for example, shipments sent to an address different from those listed on the consignment note or consignment.

\section{Conclusions}

In conclusion, the result of logistic customer service is the satisfaction of the recipient and his willingness to cooperate. The statistics provided by the X-press Couriers division of Krakow show that the level of punctuality of 
their services is very diverse. The smallest number of delays in local services is the most common service, which is Lokalny Pośpiech, and their total number does not exceed $20 \%$ of all orders in a month. The national service is also at a high level. More than $90 \%$ of consignments shipped in the most popular standard service (non-guaranteed) are shipped within 24 hours, with X-press guaranteed delivery at $89.7 \%$ and Super $X$ press $99.8 \%$. However, the effectiveness of the customer service company is best illustrated by a small number of dissatisfied customers. In 2014, the company considered only 48 complaints, of which 5 concerned the local service and 43 were domestic ones. Thus, it can be deduced from this that some of the orders considered here as "untimely" were executed over a longer period than the service provided in agreement with the customer/payer. However, such arrangements cannot be illustrated in figures.

\section{Acknowledgments}

Special thanks to the Krakow branch of the X-Press Couriers for shared data and information.

\section{References}

Cichosz, M., Nowicka, K., Pluta-Zaremba, A. (2011). Branża przesyłek kurierskich, ekspresowych i paczkowych. Centrum Doradztwa i ekspertyz gospodarczych SGH Sp. z 0.0.

Dyczkowska, J. (2005). Klient na rynku usług TSL. Zeszyty Naukowe Instytutu Ekonomii i Zarządzania.

Dz.U. nr 330. (2003).

Jacyna-Gołda, I., Pyza, D., Szczepański, E. (2015). Logistics service for companies by warehouse facilities with different configurations in the logistics network. Journal of KONES. DOI: 10.5604/12314005.1165973.

Kawa, A. (2011). Miejsce i rola branży KEP w polskiej gospodarce. Prace Naukowe Uniwersytetu Ekonomicznego we Wrocławiu, 235.

Lendzion, M. (2013). Usługi kurierskie na rynku usług logistycznych w Polsce. Zeszyty Naukowe Uniwersytetu PrzyrodniczoHumanistycznego w Siedlcach, 96.

Lorenc, A., Szkoda, M. (2015). Customer logistic service in the automotive industry with the use of the SAP ERP system. In: 20154 th International Conference on Advanced Logistics and Transport (ICALT) (pp. 18-23). IEEE. DOI: 10.1109/ICAdLT.2015.7136584.

Pliszka, M. (2008). Rynek usług kurierskich w Polsce. Słupskie Prace Geograficzne, 5.

Rutkowski, K. (2011). Branża przesyłek kurierskich, ekspresowych i paczkowych - wpływ na polską gospodarkę. Warszawa: Centrum Doradztwa i Ekspertyz Doradczych SGH Sp. z o.0.

X-press. (2017). Retrieved from: http://www.x-press.com.pl (20.05.2017).

Cite this article aS: Lorenc, A. (2018). Assessment of logistic customer service in the CEP sector on the example of Cracow. European Journal of Service Management, 1 (25), 149-156. DOI: 10.18276/ejsm.2018.25-18. 